\title{
Analysis of the Market Chain of Tilapia Fish with Floating Net Bag Cultivation in Lake Batur, Kintamani, Bangli
}

\author{
Dewa Nyoman Sadguna ${ }^{1}$, I Made Kawan ${ }^{2}$, I Gusti Ngurah Sugiana ${ }^{3}$ \\ \{Dewasadguna59@gmail.com,imadekawan@yahoo.co.id,ngurahsugiana@gmail.com,\}
}

Program Studi Manajemen Sumber Daya Perairan Fakultas Pertanian Universitas Warmadewa

\begin{abstract}
The fish cultivation business using the floating net bag (KJA) system has undergone series of growth over a long time. This method is widely used by fish farmers in Lake Batur, Kintamani, Bangli. Despite all the various developments, a major problem that persists is the fact that after production, the farmers are yet to fully maximise the marketing system. Based on this background, the purpose of this study was to find out the marketing chain system in the business models and its margins through the means of surveys. The study location was determined through purposive sampling involving 26 tilapia fish farmers using the KJA system in Lake Batur, Kedisan Village, Kintamani, Bangli. In addition, the snow ball sampling technique was used to trace the marketing institutions involved in the process of marketing. The results showed that all the fish farmers' products were distributed by retailers, hence, the marketing chain system was only through one market channel. This was mainly from the farmers, then distributed directly to the retailers with a margin of Rp. 3,000 - up to Rp. 8,000 per kilogram of fresh fish. However, the share or price received by these farmers was between 90 to $77 \%$. Therefore, it is recommended that the fish farmers distribute their products to local retailers.
\end{abstract}

Keywords: Market Chains, Marketing Margins, Floating Net Bags

\section{Pendahuluan}

Danau Batur sudah dikenal sebagai tempat usaha budidaya ikan Nila yang berkembang dan prospektif di Bali dan banyak ditekuni oleh para petani ikan di sekitar danau dengan menerapkan sistem budidaya dalam Kantong Jaring Apung. Terbukti sampai saat ini keberadaan usaha budidaya ikan Nila sistem Kantong Jaring Apung (KJA) ini masih beroperasi dengan ajeg. Sebagai salah satu pusat produksi ikan air tawar di Bali maka hasil budidaya para petani ikan Nila sistem KJA ini tidak terlepas dari permasalahan klasik setelah diproduksi, yaitu permasalahan pada bidang pemasaran sebagaimana pada umumnya pemasaran hasil-hasil produksi pertanian jenis lainnya. Hasil produksi ikan Nila budidaya petani sistem KJA ini dipasarkan melalui lembaga perantara untuk bisa tersedia dengan cepat di tangan konsumen 
langsung. Sehubungan dengan penelitian ini, menurut (Antwi, Kuwornu, Onumah, \& Bhujel, 2017) tentang analisis produktivitas dan kendala bertani ikan tilapia komersial di Ghana bahwa dari data primer diperoleh dari 41 kebun nila menggunakan multistage sampling. Data kemudian dianalisis menggunakan statistik deskriptif dan analisis regresi, dan perjanjian dalam batasan peringkat dinilai. Hasil empiris mengungkapkan bahwa nila petani di tiga kota dimana data tersebut dikumpulkan, yaitu Achavanya, Kajanya dan Dormeliam, menghasilkan output ratarata $74 \mathrm{~kg}$ per kandang ( $6 \mathrm{~m}$ x $6 \mathrm{~m}$ x $3 \mathrm{~m}$ ) sebagai ukuran produktivitas. Produktivitas peternakan kandang ditemukan dipengaruhi secara positif oleh jumlah benih, pakan dan tingkat pendidikan manajer; dan dipengaruhi secara negatif oleh ukuran kandang, tenaga kerja dan tahun pengalaman. Selain itu, kendala utama yang diidentifikasi adalah biaya input yang tinggi, kurangnya akses ke pakan dan kredit serta dalam layanan penyuluhan yang memadai dan pencurian ikan.

Hal lain juga diungkapkan oleh (Ferreira et al., 2015) tentang analisis produksi dan dampak lingkungan dari budidaya Nila dan udang putih di Thailand. Dua studi kasus dari Asia Tenggara ini digunakan untuk menganalisis produksi, dampak lingkungan, dan optimalisasi ekonomi Nila Tilapia (Oreochromis niloticus) dan budidaya tambak Udang Putih (Penaeus vannamei). Proyeksi data ini dibuat untuk Thailand. Hasilnya dianalisis pada skala regional berdasarkan pemilihan lokasi menggunakan evaluasi multi-kriteria (multi-criteria evaluation=MCE). Budaya skala pertanian disimulasikan untuk (i) monokultur nila di Chiang Rai; (ii) budidaya udang di Chanthaburi; dan (iii) Budidaya Multi-Trophic Terpadu (IMTA) oftilapia dan udang di Chon Buri. Skenario Integrated Multi-Trophic Aquaculture (IMTA) yang dimodelkan termasuk rumput laut hijau Ulva mengurangi NH4+ arus keluar ke siklus $0,32 \mathrm{~kg}^{-1}$. Penskalaan ke tingkat nasional, untuk produksi tahun $2010158.293 \mathrm{t} \mathrm{y}^{-1}$ (nila), dan $553.899 \mathrm{t} \mathrm{y}^{-1}$ (udang), memberikan emisi yang dihitung masing-masing sebesar 2.105.118 dan 34.904 Setara Penduduk (PEQ). Hanya sebagian yang merupakan eksternalitas negatif, karena sistem agroaqua pedesaan di Thailand menggunakan kembali pelepasan dalam kolam tambak, budidaya padi, dll. Nila komersial dan udang budidaya memiliki nilai tambah bagian dari total PDB 0,38, dan nilai tambah 96,24, menghasilkan dampak tidak langsung dari industri terhadap ekonomi Thailand sebesar \$ 35 juta, dan penciptaan 16.000 pekerjaan tambahan. Sejalan dengan hal di atas, sebuah penelitian datang dari (Sri Mulyani, ., \& Fitrani, 2015). Penelitian ini menunjukkan bahwa kelaparan periodik terbaik untuk pertumbuhan, efisiensi pakan dan tingkat kelangsungan hidup nila adalah P3. Selama penelitian, kualitas air dalam kisaran optimal untuk nila adalah suhu $27-29^{\circ} \mathrm{C}$, oksigen terlarut 3,73-4,99 mg.L $\mathrm{L}^{-1}$, pH 6,8-7,3, dan amonia 0,003-0,012 mg.L-1 Pemuasaan secara periodik terbaik dilihat dari pertumbuhan, efisiensi pakan dan kelangsungan hidup yaitu satu hari dipuasakan dan tiga hari diberi pakan. Menyimak uraian di atas maka kasus ini menarik untuk diteliti karena pengetahuan tentang rantai pemasaran ikan nila produksi petani ikan di Danau Batur, secara khusus, sangat membantu kegiatan pemasaran produksi ikan Nila mereka memperoleh pola pemasaran yang efisien. Oleh karena itu, berdasarkan pada uraian permasalahan di atas, maka penelitian ini bertujuan untuk 1) mengetahui pola rantai pasar ikan nila konsumsi diproduksi petani ikan Nila KJA di Danau Batur, Desa Kedisan, Kintamani, Bangli. 2) Mengetahui marjin pemasaran dari setiap lembaga pemasaran yang terlibat dalam proses rantai pasar ikan nila produksi petani ikan Nila KJA di Danau Batur, Desa Kedisan. 


\section{Metode Penelitian}

Metode dasar penelitian ini adalah deskriptif analitis, yaitu suatu kombinasi dari metode deskriptif dan metode analitis (Soeratno \& Arsyad, 1995). Teknik pelaksanaannya menggunakan metode survey (Singarimbun \& Efendi, 1995).

\subsection{Populasi dan Teknik Pengambilan Sampel}

Populasi penelitian adalah para petani pembudidaya ikan Nila sistem KJA dan lembagalembaga pemasaran yang terlibat dalam proses pemasaran ikan produksi pembudidaya ikan Nila KJA Danau Batur di Desa Kedisan. Sampel pembudidaya diambil secara Sensus berjumlah 26 orang. Sedangkan sampel para pelaku pasar yang terlibat diperoleh dengan teknik snow ball sampling (Irianto \& Mardikanto, 2011). Disamping itu, Lokasi penelitian ini ditentukan secara purposive sampling, yaitu pada petani ikan Nila KJA di Desa Kedisan, Danau Batur, Kintamani, Bangli. Pertimbangannya adalah bahwa lokasi ini sudah dikenal sebagai salah satu sentra penghasil ikan air tawar terbesar di Bali, yang tentu saja akan mempunyai berbagai permasalahan kompleks, seperti bidang pemasaran. Selain itu lokasi ini mempunyai sumber daya manusia tenaga kerja yang mendukung pengembangan komoditi ikan budidaya. Pemerintah Kabupaten Bangli juga mendukung perkembangan budidaya perikanan di Danau Batur. Terakhir, belum pernah ada penelitian serupa berkaitan dengan sistem pemasaran usaha budidaya ikan konsumsi di Danau Batur.

\subsection{Data Penelitian dan Teknik Pengumpulan Data}

Data peneltian ini adalah data kuantitatif dan kualitatif yang diperoleh dari sumber primer dan skunder. Data kuantitatif seperti jumlah produksi, harga, biaya-biaya pemasaran. Data kualitatif seperti uraian tentang rantai pasar, sistem pembayaran, dan informasi pasar. Data primer berasal antara lain dari para petani ikan ataupun para pelaku pasar yang terlibat. Data sekunder antara lain dari dokumentasi data pemerintah, publikasi jurnal atau hasil-hasil penelitian sebelumnya.Data dikumpulkan melalui: a) wawancara dengan menggunakan kuesioner terstruktur yang telah disiapkan; b) observasi langsung pada obyek yang diteliti seperti perilaku petani dalam melakukan proses pemasaran; dan c) studi kepustakaan.

\subsection{Teknik Analisis Data}

Data yang telah terkumpul dilakukan tabulasi dan selanjutnya diadakan analisis, baik secara kualitatif dan kuantitatif. Untuk aspek kondisi usaha budidaya ikan Nila KJA dan aspek rantai pasar dianalisis secara kualitatif, sedangkan marjin pasar dari lembaga-lembaga pemasaran yang terlibat dianalisis secara kuantitatif. Model yang digunakan untuk menghitung marjin pemasaran (Sudiyono, 2004) adalah:

$$
\begin{aligned}
& \mathrm{MP}=\mathrm{Pr}-\mathrm{Pf} \text { atau }(1) \\
& \begin{array}{llll}
\mathrm{N} & \mathrm{n} & \mathrm{n} & \mathrm{n}
\end{array} \\
& \mathrm{MP}=\sum_{\mathrm{i}=1} \mathrm{Bpi}+\sum_{\mathrm{i}=1} \mathrm{Kpi} ; \quad \mathrm{Bpi}=\sum_{\mathrm{i}=1} \text { bij } \quad \mathrm{Kpi}=\mathrm{Pji}-\mathrm{Pbi}-\underset{\mathrm{I}=1}{\sum} \mathrm{bij}
\end{aligned}
$$

dimana: 


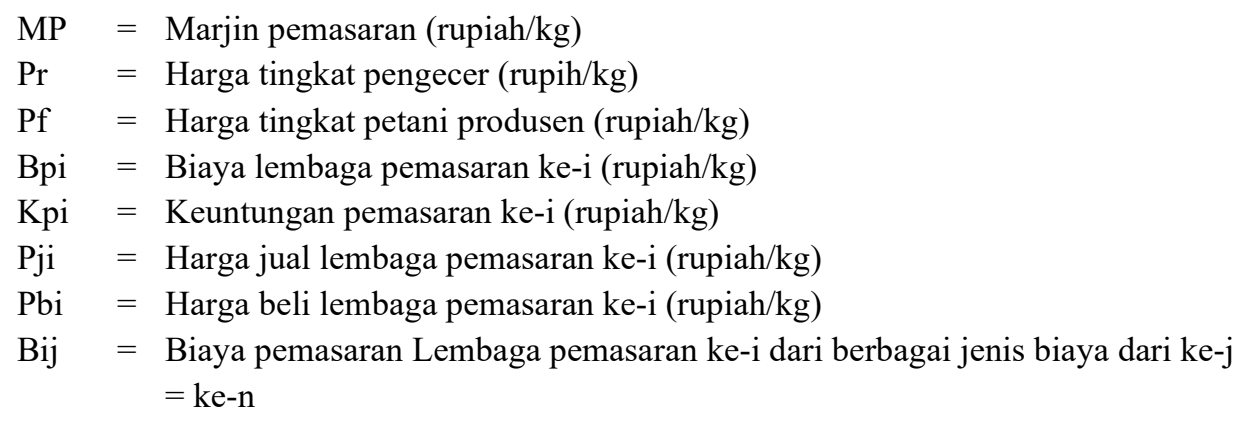

Sistem pemasaran yang efisien, bila semakin kecilnya perbedaan antara harga yang diterima petani dan harga yang dibayar konsumen. Apabila semakin besar marjin pemasaran ini akan menyebabkan harga yang diterima petani ikan produsen menjadi semakin kecil dan semakin mencerminkan adanya sistem pemasaran yang tidak efisien.

\section{Hasil Dan Pembahasan}

\subsection{Pola Pembiayaan Usaha Budidaya Ikan Nila KJA Desa Kedisan}

Dalam pembiayaan usaha kecil dikenal dua sistem, yaitu langsung dan tidak langsung. Pembiayaan langsung biasanya bersumber dari aliran dana rumah tangga, antar pemerintah, antar perusahaan, atau diantara mereka. Sedangkan pembiayaan tidak langsung melibatkan lembaga keuangan seperti perbankan. Untuk usaha budidaya ikan sistem KJA petani ikan Nila Desa Kedisan rata-rata pada awalnya menggunakan dana sendiri, kemudian setelah usahanyanya berjalan cukup baik, maka dapat menggunakan pola pembiayaan melalui bank, khususnya KUR BRI, karena akses ke lembaga keuangan ini dirasakan lebih mudah, apalagi dengan adanya sistem KUR yang suku bunganya rendah. Jadi modal usaha yang digunakan pembudidaya ikan Nila KJA di Desa Kedisan untuk usahanya bersumber dari kombinasi dari sumber dana sendiri dan sumber perbankan. Permodalan yang ada ini dimanfaatkan untuk pembelian bibit dan pakan ikan, serta untuk keperluan pembuatan keramba.

Pada usaha budidaya ikan Nila KJA ini diawali dengan modal sendiri, setelah berjalan baik dan mendapat bimbingan, pendampingan, serta pembinaan dari Dinas Perikanan barulah kemudian punya peluang besar memperoleh bantuan/kredit dari perbankan. Jumlah bantuan kredit permodalan ini diberikan sesuai dengan kelayakan usaha budidaya ikan, kemampuan dan skala usahanya. Agunan bank umumnya berupa sertifikat tanah, karena usaha KJA tidak dapat dijadikan agunan. Disamping berupa agunan, maka untuk mendapatkan kredit dari perbankan ini petani ikan KJA harus mendapat rekomendasi dari dinas terkait.

\subsection{Proses Produksi Usaha Budidaya ikan Nila KJA Desa Kedisan}

Sebagaimana usaha budidaya ikan KJA pada umumnya, maka budidaya ikan Nila KJA di Danau Batur oleh petani lkan Nila di Desa Kedisan adalah termasuk usaha mikro kecil yang rentan dengan beberapa kelemahan. Oleh karena itu, bantuan dari berbagai pihak sangat 
dibutuhkan dalam upaya meningkatkan usaha. Terutama program pendampingan, pelatihan, serta pola dan akses pasar sehingga tujuan mensejahterakan petani dapat tercapai.

Rata-rata kepemilikan KJA oleh petani ikan Nila di Danau Batur, Desa Kedisan adalah 15 plong dengan biaya investasi rata-rata Rp. 6.000.000,- per plong, satu plong memiliki ukuran 4 x 4 x 3 meter dengan kapasitas 1.500 bibit ikan dengan rata-rata size $9 \mathrm{~cm}$. Pemberian pakan untuk satu siklus pemeliharaan rata-rata 6 (enam) zak dengan tenaga kerja satu orang, masa pemeliharaan selama 5 (lima) bulan dengan panen seberat $200 \mathrm{~kg}$ per plong. Dengan perhitungan biaya-biaya dan investasi seperti itu maka harga pokok atau biaya total per kilogram ikan Nila petani adalah sebesar Rp. 24.736,-. Semetara harga ikan konsumsi per kilogram dijual langsung di tempat oleh pembudidaya kepada pengecer lokal ataupun pengecer non lokal (luar daerah) setempat rata-rata sebesar Rp. 27.000.000,-. Kalau pengecer lokal tersebut kemudian menjualnya di sekitaran danau maka harga jualnya berkisar Rp. 30.000,- Namun kalau di jual di kota Kabupaten maupun Provinsi oleh pengecer non lokal ke konsumen langsung maka harga jual ikan tersebut sampai mencapai Rp. 35.000,- per kilogram. Petani pembudidaya ikan KJA Desa Kedisan lebih menyukai memelihara jenis ikan nila, karena beberapa pertimbangan, antara lain karena ikan Nila mempunyai pertumbuhan yang relatif cepat dan dapat dipelihara dengan kepadatan yang tinggi, tidak perlu persyaratan kualitas air yang rumit, kemudian pemberian pakannya bisa lebih efisien, rasa dagingnya enak dan dapat diterima oleh segala lapisan masyarakat, sehingga potensi pasarnya kedepan tentu akan lebih menjanjikan dan prospektif. Seluruh usaha budidaya ikan Nila KJA ini mendapat ijin dari desa, dan dikukuhkan oleh Dinas Perikanan Kabupaten Bangli. Sebagai usaha mikro kecil, mereka juga sering menghadapi pasar yang tidak menentu terutama dari sisi masukan (pasokan bibit kurang, harga pakan mahal). Sedangkan dari sisi keluaran, untuk pemasaran hasil masih bisa diterima oleh petani dilihat dari segi pendapatan dan keuntungan usaha. Umumnya dalam proses tawar-menawar harga jual petani pembudidaya umumnya berdasarkan kepada kesepakatan namun tanpa mengabaikan rujukan pada harga pasar.

\subsection{Faktor Risiko Usaha Budidaya Ikan Nila KJA Desa Kedisan}

Untuk jenis usaha pada budidaya ikan Nila oleh petani ikan KJA di Desa Kedisan ada beberapa risiko yang perlu mendapat perhatian, karena bisa berdampak pada keberlangsungan usaha budidaya ikan, menyangkut aspek teknis, biologis, sosial, dan ekonomis.

Pada aspek teknis berhubungan dengan lingkungan perairan danau, seperti kondisi kualitas air. Adanya perubahan pada kualitas air dapat disebabkan oleh adanya residu atau sisa-sisa pemanfaatan obat-obatan dan zat-zat kimia lainnya pada aktivitas pertanian di sekitar pinggiran danau yang dapat beracun bagi ikan, sehingga berakibat kematian ikan. Tingginya tingkat erosi lahan, khususnya pada saat musim hujan akan meningkatkan kekeruhan air, apalagi bila ditambah dengan aktivitas pemberian pakan yang kadang berlebihan akan mengakibatkan penetrasi cahaya semakin kecil dan akibatnya akan menggangu pertumbuhan ikan. Risiko dari aspek biologis, adalah berkaitan dengan pertumbuhan ikan di masa pemeliharaan yang mungkin bisa muncul adanya serangan penyakit/hama yang akan bisa mengakibatkan ikan tidak bisa tumbuh secara optimal. Walaupun sampai saat ini para pembudidaya ikan masih merasa optimis, karena ikan budidaya mereka masih bisa tumbuh dengan baik. Sedangkan dari aspek sosialnya, 
dimana ada kemungkinan timbulnya rasa cemburu sosial, karena ada sebagian anggota masyarakat di sekitaran danau yang mungkin ada merasa tidak diuntungkan. Yang mana hal ini bisa terjadi bisa disebabkan oleh penguasaan/perebutan lahan, penggunaan tenaga kerja, atau mungkin aturan yang diterapkan dalam menertibkan usaha atau dalam rangka menjaga batas maksimal penggunaan areal danau, dan lain-lain. Kemudian risiko dari aspek ekonomis adalah terkait dengan keberlangsungan usaha budidaya ikan Nila KJA yang sangat dipengaruhi oleh adanya harga pakan yang sering berfluktuasi naik/dinamis, sehingga kondisi ini akan berpengaruh pada biaya produksi. Dampaknya pada usaha yang menjadi kurang memberi keuntungan sesuai harapan. Apalagi pada usaha budidaya ikan Nila KJA ini pemberian pakan berpengaruh sangat signifikan bagi kualitas petumbuhan ikan nila yang kemudian akan berefek pada kelangsungan usaha budidaya ikan nila.

\subsection{Pola Pemasaran Hasil Usaha Budidya Ikan Nila KJA Desa Kedisan}

\subsubsection{Permintaan dan Penawaran}

Laporan data Dinas Perikanan Kelautan Perikanan Provins Bali, 2018, konsumsi ikan budidaya air tawar di Bali sampai saat ini mencapai 10 - 12 ton per hari. Sedangkan pasokan dari para petani ikan air tawar di Bali hanya mampu memenuhi kira-kira 20 persen dari kebutuhan konsumsi tersebut, sehingga harus didatangkan dari luar Pulau Bali, khususnya dari Jawa Timur ataupun dari Jawa Barat. Kondisi ini mencerminkan bahwa potensi permintaan ikan air tawar di Bali akan semakin terbuka. Apalagi kemudian konsumsi ikan masyarakat mempunyai kecenderungan meningkat setiap tahunnya sejalan dengan kesadaran masyarakat tentang pemenuhan gizi lauk hewani yang paling baik dan aman dari sisi kesehatan adalah makan ikan, dan secara ekonomis harganya relatif murah dibandingkan dengan harga lauk dari daging, terutama daging sapi bahkan daging ayam. Sementara itu konsumsi ikan per kapita mengalami peningkatan sebesar $5,04 \%$, sehingga permintaan akan lauk ikan mempunyai prospek yang sangat cerah di masa mendatang. Kondisi seperti ini berdampak pada semangat para petani ikan Nila sistem budidaya KJA di Desa Kedisan untuk berproduksi sepanjang tahun. Apalagi sejauh ini mereka sudah memiliki pelanggan tetap dari beberapa daerah di Bali, seperti dari Denpasar, Badung, dan masyarakat Bangli sendiri, terutama restoran-restoran di sekitaran Kintamani. Para pembeli datang sendiri ke tempat usaha budidaya sehingga petani pembudidaya dapat melayani langsung di tempat setelah ada panen tanpa mengeluarkan biaya tambahan berupa biaya transportasi.

Dalam penjualan ikan Nila hasil budidaya sistem KJA ini dijual dengan ukuran berat per kilogram yang akan berisi 3 (tiga) ekor sampai 4 (empat) ekor ikan. Ikan yang dijual tersebut dalam kondisi masih segar atau dalam keadaan hidup tanpa ada pengemasan.

\subsubsection{Saluran Pemasaran Hasil Budidaya Ikan Nila KJA Desa Kedisan}

Saluran pemassaran (marketing chanel) merupakan suatu alur lalulintas suatu produk dari produsen ke konsumen sehingga produk ataupun jasa dapat tersedia untuk dimanfaatkan ataupun dikonsumsi oleh konsumen. Sehingga saluran pemasaran produk ini dapat berfungsi 
sebagai penghubung antara pembudidaya ikan NIla sistem KJA di Desa Kedisan dengan konsumen akhir, seperti orang pribadi, rumah makan, restoran, maupun hotel. Dengan tersedianya saluran pemasaran membuat para petani ikan Nila sistem budidaya KJA mempunyai jaminan kepastian berusaha, karena setiap panen seluruh hasil produksi akan dapat terserap oleh pasar. Berdasarkan saluran pemasaran yang dilalui, maka jumlah produksi ikan yang dipasarkan, jumlah lembaga pemasaran yang terlibat, jarak petani ikan ke konsumen, panjangnya alur pemasaran yang dilalui, dan daerah tujuan pasar akan dapat membedakan besarnya biaya yang dikeluarkan dalam aktivitas pemasaran, sehingga selanjutnya akan dapat mempengaruhi besarnya marjin pemasaran, bagian keuntungan dan biaya dari tiap lembaga pemasaran serta bagian harga yang diperoleh petani.

Saluran pemasaran ikan hasil budidaya petani ikan Nila KJA Desa Kedisan, mempunyai satu tipe saluran pemasaran, yang mana di dalam tipe saluran pemasaran tersebut ada terlibat hanya satu lembaga pemasaran, yaitu pedagang pengecer, baik pengecer lokal (di sekitaran danau di Desa Kedisan) maupun pengecer non lokal (daerah Bangli, Denpasar, dan Badung). Ini adalah pola saluran pemasaran yang sangat sederhana. Berdasarkan observasi yang dilakukan, persaingan diantara para petani pembudidaya ikan Nila nyaris tidak terjadi, karena hasil panen mereka selalu dapat diserap oleh pasar, serta hubungan diantara pembudidaya dan lembaga pemasaran yang terlibat seperti pengecer tersebut adalah sangat harmonis, saling menghormati profesi masing-masing. Petani ikan sebagai produsen tetap bergerak sebagai produsen dan tidak ingin juga bergerak atau mengambil peran pedagang perantara yang diperkirakan akan dapat merusak harga daripada pedagang pengecer yang telah menjadi langganan penyaluran ikan produksinya terhadap konsumennya tersebut.

\subsubsection{Marjin Pemasaran dan Bagian Harga yang Diterima Petani ikan Nila}

Marjin pemasaran adalah selisih harga pada tingkat pedagang pengecer dengan harga jual pada tingkat petani pembudidaya ikan Nila atau penjumlahan biaya-biaya yang dikeluarkan dengan perolehan keuntungan lembaga-lembaga pemasaran yang terlibat pada proses pemasaran ikan tersebut. Menganalis marjin pemasaran ditujukan untuk mengetahui tingkat kompetensi dari para pelaku pasar yang terlibat dalam proses pemasaran serta bagian (share) harga yang diperoleh petani. Semetara itu Saliem (2004) dalam Parwati, dkk. (2005) menyebutkan, bahwa menganalisis marjin pemasaran adalah bertujuan untuk melihat efisiensi pemasaran, dimana dicerminkan oleh besarnya keuntungan yang diperoleh masing-masing para pelaku pasar. Apabila semakin tinggi proporsi harga yang didapatkan oleh para petani produsen, maka sistem pemasaran tersebut dikatakan semakin efisien.

Marjin pemasaran ikan Nila produksi petani ikan KJA Desa Kedisan dianalisis dari arus pemasarannya mulai dari harga per kilogram yang diterima oleh petani ikan Nila sampai harga per kilogram yang diterima oleh pedagang pengecernya. Petani pembudidaya ikan Nila menjual produknya dalam bentuk segar tanpa dikemas berisi 3 - 4 ekor ikan Nila per kilogram. Begitupun pedagang pengecer tidak memberikan perlakuan apapun terhadap ikan Nila yang dibelinya dari petani ikan Nila tersebut. Sementara itu, bagian (share) harga yang diterima petani ikan Nila KJA adalah merupakan perbandingan atau rasio antara harga jual ikan Nila di tingkat petani ikan dengan harga jual ikan Nila di tingkat pengecer atau persentase bagian harga yang 
diterima petani ikan Nila dari harga yang dibayarkan oleh konsumen, dimana bila semakin tinggi proporsi harga yang diterima oleh petani pembudidaya ikan Nila, maka sistem pemasaran ikan Nila tersebut dinilai semakin efisien. Disimak dari rantai pemasaran ikan Nila produksi dari petani pembudidaya ikan Nila KJA di Danau Batur, Desa Kedisan, maka bagian harga yang diterima oleh petani pembudidaya ikan Nila adalah sama antara pedagang pengecer lokal dengan pedagang pengecer non lokal. Namun bila rantai pemasarannya lebih panjang, maka tentu akan memperbesar marjin pemasaran, sehingga akan mengakibatkan bagian harga yang diterima petani pembudidaya ikan Nila dari harga jual yang telah dibayarkan oleh konsumen akan menjadi semakin kecil, sehingga kondisi ini dapat menunjukkan efisiensi pemasaran ikan Nila adalah rendah.

Perhitungan marjin pemasaran dan harga yang diterima petani dari harga yang dibayarkan oleh konsumen dapat dilihat pada Tabel 1.

Tabel 1 Marjin Pemasaran dan Bagian Harga yang Diterima Petani Ikan Nila Sistem KJA di Danau Batur, Desa Kedisan, Tahun 2019

\begin{tabular}{ccccc}
\hline Pengecer & $\begin{array}{c}\text { Harga jual petani } \\
\text { ikan Nila } \\
(\mathrm{Rp} / \mathrm{kg})\end{array}$ & $\begin{array}{c}\text { Harga beli } \\
\text { konsumen } \\
(\mathrm{Rp} / \mathrm{kg})\end{array}$ & $\begin{array}{c}\text { Marjin } \\
\text { pemasaran } \\
(\mathrm{Rp} / \mathrm{kg})\end{array}$ & $\begin{array}{c}\text { Bagian Harga } \\
\text { petani ikan } \\
(\%)\end{array}$ \\
\hline Lokal & $27.000,-$ & $30.000,-$ & $3.000,-$ & 90,00 \\
Non lokal & $27.000,-$ & $35.000,-$ & $8.000,-$ & 77,14 \\
\hline Rata-Rata & $27.000,-$ & $32.500,-$ & $5.500,-$ & 83,57 \\
\hline
\end{tabular}

Memperhatikan Tabel 5.1 di atas bahwa pembagian marjin pemasaran yang diperoleh pengecer per kilogram adalah sebesar Rp. 3000,- untuk pengecer lokal dan Rp. 8.000,- diperoleh pengecer non lokal. Sementara itu bila dibandingkan dengan perolehan petani yang mengeluarkan biaya-biaya sampai Rp. 24.736 ,- per kilogramnya maka margin yang diperoleh petani adalah lebih kecil, hal ini mencerminkan proses pemasaran ikan Nila petani pembudidaya ikan Desa Kedisan dianggap belum efisien. Sementara itu rata-rata bagian (share) harga yang diperoleh petani pembudidaya ikan Nila KJA di Danau Batur, Desa Kedisan sebesar adalah 83,57 persen dari saluran pemasaran ikan Nila mereka. Namun demikian, kalau petani pembudidaya ikan Nila menyalurkan ikan Nilanya kepada pengecer lokal maka bagian harga yang diterima petani ikan akan lebih besar, yaitu 90 persen dibanding ke pengecer non lokal yang memberikan bagian harga lebih kecil, yaitu 77,14 persen. Hal ini memberi arti bahwa penyaluran produk ke penngecer lokallah yang lebih efisien untuk dipilih oleh petani ikan.

\section{Kesimpulan}

Simpulan yang dapat disampaikan dari proses penelitian pemasaran ikan Nila produksi petani pembudidaya ikan sistem KJA di danau Batur, Desa Kedisan, Kintamani, Bangli adalah sebagai berikut: 1) Terdapat satu sistem saluran pemasaran ikan Nila produksi petani pembudidya ikan sistem KJA di Danau Batur, Desa Kedisan, yaitu dari petani ikan langsung ke 
pedagang pengecer; 2) Marjin pemasaran dari setiap lembaga pemasaran yang terlibat dalam proses rantai pasar ikan nila yang diproduksi petani ikan Nila KJA di Danau Batur, Kintamani, Bangli adalah sebesar Rp 3.000,- sampai Rp. 8.000,- masing-masing untuk pedagang pengecer lokal dan pedagang pengecer non lokal dengan bagian (share) harga yang diterima petani dari masing-masing pedagang pengecer lokal sebesar $90 \%$ dan pedagang pengecer non lokal sebesar 77,14 persen. Dalam pelaksanaan kegiatan pemasaran, pembagian atas balas jasa, yaitu marjin pemasaran di antara lembaga perantara yang terlibat adalah timpang, dimana marjin pemasaran terbesar diperoleh pedagang pengecer non lokal dibandingkan pedagang pengecer lokal. Walaupun nilai bagian (share) harga petani pembudidaya ikan Nila ini terlihat lebih besar dari pada bagian (share) biaya dan keuntungan pedagang pengecer, namun hal ini bersifat relatif, karena korbanan terbesar yang dilakukan petani pembudidaya ikan dalam proses budidayanya masih tidak sepadan dengan korbanan yang nyaris tidak ada dari pedagang pengecer dalam aktivitas pemasarannya. Hal ini mengindikasikan proses pemasaran ikan Nila petani pembudidaya di Danau Batur, Desa Kedisan belumlah efisien.

\section{References}

Antwi, D. E., Kuwornu, J. K. M., Onumah, E. E., \& Bhujel, R. C. (2017). Productivity and constraints analysis of commercial tilapia farms in Ghana. Kasetsart Journal of Social Sciences, 38(3), 282 290. https://doi.org/10.1016/j.kjss.2016.12.001

Ferreira, J. G., Falconer, L., Kittiwanich, J., Ross, L., Saurel, C., Wellman, K., ... Suvanachai, P. (2015). Analysis of production and environmental effects of Nile tilapia and white shrimp culture in Thailand. Aquaculture, 447, 23-36. https://doi.org/10.1016/j.aquaculture.2014.08.042

Irianto, H., \& Mardikanto, T. (2011). Metoda Penelitian dan Evaluasi Agribisnis. Semarang: Jurusan/Program Studi Agribisnis Fakultas Pertanian UNS.

Singarimbun, M., \& Efendi, S. (1995). Metode Penelitian Survei. Jakarta: LP3ES.

Soeratno, \& Arsyad, L. (1995). Metodologi Penelitian untuk Ekonomi dan Bisnis. Yogyakarta: YKPN.

Sri Mulyani, Y., . Y., \& Fitrani, M. (2015). Pertumbuhan dan Efesiensi Pakan Ikan Nila (Oreochromis niloticus) yang Dipuasakan Secara Periodik. Jurnal Akuakultur Rawa Indonesia, 2(1), 1-12.

Sudiyono. (2004). Pemasaran Pertanian. Malang: Universitas Muhamadiyah Malang (UMM) Press. 